\title{
EFFECT Of CERTAIN INSECTICIDES ON THE PIOTIC POTENTIAL OF THE COTTON LEAFWORM, SPODOPTERA LITTORALIS(BOISD.)
}

\author{
AREF, S. A. ${ }^{1}$, O.CH. BAYOUMI ${ }^{2}$ AND HEBA A.B. SOLIMAN ${ }^{1}$ \\ 1. Plant Protection Research Institute ARC, Dokki, Giza \\ 2. Faculty of Agriculture, Kafrelsheikh University
}

(Manuscript received 13 July 2008)

\begin{abstract}
Treated leaves of Castor bean oil with LC50 and Lc25 of Diflubenzuron were offered to $4^{\text {th }}$ instar larvae of cotton leafworm, Spodoptera littoralis (Boisd.) for 48 hours. The percentage of mortality showed $60.71 \%$ and $33.92 \%$ respectively. The larval period was increased with $60.01 \%$ and $37.5 \%$ - The increase of pupal period showed $55.5 \%$ and $42.67 \%$ - Data gave an increase of the pre- oviposition period with $200.54 \%, 81.96 \%$ and decrease of pupal weight with $27.84 \%, 14.76 \%$. The abnormal percentage of pupl stage reached $55.23 \%$ and $32.14 \%$, while the abnormal percentage of moths stage increased with $41.67 \%$ and $19.04 \%$. The number of eggs / female reduced by $86.27 \%$, $79.48 \%$, while sterility percentage reached $90.32 \%, 82.37 \%$ compared with control. While, treated leaves of castor bean oil with LC50 and LC 25 of Bacillus thuringiensis against $2^{\text {nd }}$ instar larvae after feeding 48 hours proved the following : The percentage of mortality $72.41 \%$ and $51.72 \%$. The larval period increased with $24.74 \%, 13.31 \%$. Increase the pupal period with $38.5 \%$ and $10.80 \%$. Increase the pre- oviposition period with $237.91 \%$ and $115.16 \%$. Decrease pupal weight with $21.23 \%$, $14.60 \%$ - Increase the abnormal percentage of pupa stage with $72.08 \%$ and $26.57 \%$ - Increase the abnormal percentage of moths stage with $70.83 \%$ and $39.60 \%$ - Reduce the number of eggs / female by $92.42 \%$ and $84.79 \%$. Sterility percentage with $93.80 \%, 86.74 \%$ compared with control. Data revealed that Lc50 and Lc25 of Lettuce oil extract after 48 hours of feeding $2^{\text {nd }}$ instar larvae on treated castor bean oil leaves increased the following : The percentage of mortality reached $67.24 \%$ and $62.06 \%$. The larval period was decreased to $27.34 \%, 12.57 \%$. The pupal period showed an decrease with $33.93 \%, 14.91 \%$ decrease the pre- oviposition period with $57.97 \%, 31.59 \%$ Increase pupal weight with $35.39 \%, 30.97 \%$ - Increase the abnormal percentage of pupa stage with $51.25 \%, 12.39 \%$ Reduce the number of eggs / female by $85.93 \%, 80.47 \%$ - and didn't effect on moths, hatchability and sterility . compared with control .
\end{abstract}

\section{INTRODUCTION}

The cotton leafworm , S. littoralis is one of the most important insect pests attacking cotton, vegetables and field crops and causes serious damage to them. 
Chemical control in the field caused the pollution of the enviroment and developed tolerance acquired by its successive generations subjected to insecticides .

Insect growth regulatrous (IGRS) are insecticides acting on various insect orders by disrupting chitin synthesis. The major effect of members of these group is upon those period of the life cycle where chitin is being formed and where its incorrect or insufficient production can lead to malformation of later stages of the life cycle . Many authors investigated IGR'S on S . littoralis, Ishaaya et al . (1986), EL- Deeb et al. (1991) , EL-Shoura , Aly (1994), Gomaa et al .(1996) and Korkor et al. (1996).

The wide use of the chemical compounds has resulted many problems such as population outbreaks and chemical resistance, endangering human health and wealth. Therefore, the world decided to reduce chemicals use and tried to introduce predators and biocontrol agents such as virus, bacteria and fungi for controlling the pests through I.P.M. Programs. The present study was carried out to evaluate the sublethal doses of B. thuringiensis (agrein), lettuce oil extract and diflubenzuran (I.G.R.) on some biological aspects of $2^{\text {nd }}$ and $4^{\text {th }}$ instar larvae of cotton leafworm, compared with profenofos .

\section{MATERIALS AND METHODS}

\section{Chemical tests:}

1.1. Insecticides: Organophosphorus insecticides: Profenofos (Acron, $72 \%$ E.C.)

1.2. Pyrethroids: Lambda-cyhalothrin (Lambda, $5 \%$ E.C.)

1.3. Insect growth regulators (I.G.R.): Diflubenzuron (Demeron, $10 \%$ E.C.)

2. Bacterial insecticides (biocide): Bacillus thuringiensis.

Agerin, 6.5\% WP (contain $32000 \mathrm{IU} / \mathrm{mg}$ ) .

\section{Plant extracts: Oil extraction from lettuce leaves}

Fifty grams of untreated lettuce plants Lactuca sativa (L.) were collected from Kafr ElSheikh Farm then washed with distilled water to clean it from different soil wastes. Leaves were kept at room temperature to dry .

Dried leaves were cut into small parts and then were extracted with petroleum ether in a Blender at high speed and at room temperature. The petroleum ether extract was then filtered on a filter glass G4. The residues on the filter glass were washed twice with $50 \mathrm{ml}$ of petroleum ether. The filtrates were combined and evaporated into a rotatory evaporator to dryness. The crude oil extract was cleaned on a chromatographic column using a granulated florisil (60-80 mesh) and eluted with a mixture of acetone-petroleum ether (1: $3 \mathrm{v}: \mathrm{v})$. The elution were combined and 
evaporated in a vacuum rotatory evaporator to eliminate the solvents used in the above steps. The obtained oil was used in different experimental tests.

\section{Laboratory strain of cotton leafworm:}

Laboratory strain of cotton leafworm, $S$ - littoralis were obtained from Agriculture Research Center at Kafr El-Sheikh, reared for several generation on castor bean oil leaves (Ricinus communis) under controlled conditions of $26 \pm 2^{\circ} \mathrm{C}$ and $65 \pm$ $5 \% \mathrm{RH}$.

\section{Effect on some biological aspects of $\boldsymbol{S}$. littoralis}

This study was conducted to evaluate the effect of diflubenzuran (I.G.R.) on some biological aspects of the $4^{\text {th }}$ instar larvae of $S$. littoralis, while $B$. thuringiensis (agerin) and lettuce oil extract were evaluated against $2^{\text {nd }}$ instar larvae.

Diflubenzuron, $B$. thuringiensis and lettuce oil extract were tested at $\mathrm{LC}_{50}$ and $\mathrm{LC}_{25}$ concentration. Twenty larvae were placed into a glass jars and reared on treated castor leaves for 48 hours. Each treatment was replicated three times. The exposed larvae were transferred into a clean jars and then provided with untreated castor bean oil leaves until pupation.

Larvae were examid daily for mortality percentage, larval and pupal duration, percent of pupation, pupal weight, malformation in either pupal and adult stage, preoviposition period, hatchability and sterility of adult females. Percent sterility was calculated using Chamberlain formula (1962) which was modified by Toppozada et al. (1966) as follows:

$$
\% \text { sterility }=100-\frac{\mathrm{a} \times \mathrm{b}}{\mathrm{A} \times \mathrm{B}} \times 100
$$

\section{Where:}

$\mathrm{a}=$ number of eggs laid/female in treatment.

$\mathrm{b}=\%$ of hatchability in treatment.

$\mathrm{A}=$ number of eggs laid/female in untreated control.

$\mathrm{B}=\%$ of hatchability in untreated control.

\section{Equations used for estimating different bio-metric records of $\boldsymbol{S}$. littoralis}

1. Pupation $\%=\frac{\text { Totalnumber of pupae }}{\text { Totalnumber of treatedlarvae }} \times 100$

2. Pupal malformation $\%=\frac{\text { Number of abnormal pupae }}{\text { Number of (normal }+ \text { abnormal) pupae }} \times 100$

3. Abnormal moths emergence $\%=\frac{\text { Number of abnormalmoths }}{\text { Totalnumber emergent moths }} \times 100$ 
4. Reduction percent of pest numbers $\%=100\left[1-\frac{T}{C}\right]$

5. Increment percent of pest numbers $\%=100\left[\frac{T}{C}-1\right]$

\section{Where:}

$\mathrm{T}=$ Pest number in the treatment

$C=$ Pest number in the control.

According to El-Dewy (2006).

\section{RESULTS AND DISCUSSION}

Data presented in Tables (1 and 2) showed that diflubenzuron at $\mathrm{LC}_{50}$ and $\mathrm{LC}_{25}$ levels exhibited $(60.71 \%, 33.92 \%)$ mortality against $4^{\text {th }}$ instar larvae. While $B$. thuringiensis (agerin) and lettuce oil extract showed (72.41\%, 51.72\%) and $(67.24 \%$, $62.06 \%$ ) mortality against $2^{\text {nd }}$ instar larvae, respectively.

Table 1 . Effect of agerin and lettuce oil extract on biotic potential of different stages of $S$. littoralis feeding as $2^{\text {nd }}$ instar larvae .

\begin{tabular}{|c|c|c|c|c|c|c|}
\hline \multicolumn{2}{|c|}{ Organic compounds } & \multicolumn{2}{|c|}{ Agerin } & \multicolumn{2}{|c|}{ Lettuce oil extract } & \multirow[b]{2}{*}{ Control } \\
\hline \multicolumn{2}{|r|}{ Developmental stages } & $\begin{array}{c}\mathrm{LC}_{25} \\
\left(9.5 \times 10^{3} \mathrm{ppm}\right)\end{array}$ & $\begin{array}{c}\mathrm{LC}_{50} \\
\left(19.3 \times 10^{3}\right. \\
\mathrm{ppm})\end{array}$ & $\begin{array}{c}\mathrm{LC}_{25} \\
\left(2.4 \times 10^{4} \mathrm{ppm}\right)\end{array}$ & $\begin{array}{c}\mathrm{LC}_{50} \\
\left(3.64 \times 10^{4} \mathrm{ppm}\right)\end{array}$ & \\
\hline 1 & Mortality (\%)during larval stage & 51.72 & 72.41 & 62.06 & 67.24 & 3.34 \\
\hline 2 & Larval stage (days) & $\begin{array}{c}39.66 \pm 1.15 \\
(+13.31)\end{array}$ & $\begin{array}{c}43.66 \pm 1.15 \\
(+24.74)\end{array}$ & $\begin{array}{c}30.6 \pm 1.52 \\
(-12.57)\end{array}$ & $\begin{array}{c}25.43 \pm 1.52 \\
(-27.34)\end{array}$ & $35 \pm 1$ \\
\hline 3 & Pupal stage (days) & $\begin{array}{l}24.00 \pm 1 \\
(+10.80)\end{array}$ & $\begin{array}{l}30.00 \pm 2 \\
(+38.50)\end{array}$ & $\begin{array}{c}18.43 \pm 0.57 \\
(-14.91)\end{array}$ & $\begin{array}{c}14.31 \pm 1.52 \\
(-33.93)\end{array}$ & $21.66 \pm 0.57$ \\
\hline 4 & Pre-oviposition period (days) & $\begin{array}{c}13.62 \pm 2.08 \\
(+115.16)\end{array}$ & $\begin{array}{c}21.39 \pm 2.08 \\
(+237.91)\end{array}$ & $\begin{array}{c}4.33 \pm 0.57 \\
(-31.59)\end{array}$ & $\begin{array}{c}2.66 \pm 0.57 \\
(-57.97)\end{array}$ & $6.33 \pm 0.57$ \\
\hline 5 & Average weight of pupae (gm) & $\begin{array}{c}0.193 \pm 0.008 \\
(-14.60)\end{array}$ & $\begin{array}{c}0.178 \pm 0.004 \\
(-21.23)\end{array}$ & $\begin{array}{c}0.296 \pm 0.005 \\
(+30.97)\end{array}$ & $\begin{array}{c}0.306 \pm 0.006 \\
(+35.39)\end{array}$ & $0.226 \pm 0.004$ \\
\hline 6 & Pupation (\%) & $\begin{array}{c}46.66 \\
(-51.73)\end{array}$ & $\begin{array}{c}26.66 \\
(-72.42)\end{array}$ & $\begin{array}{c}36.66 \\
(-62.03)\end{array}$ & $\begin{array}{c}31.66 \\
(-67.24)\end{array}$ & 96.66 \\
\hline 7 & Abnormal pupae (\%) & $\begin{array}{c}26.57 \\
(+26.57)\end{array}$ & $\begin{array}{c}72.08 \\
(+72.08)\end{array}$ & $\begin{array}{c}12.39 \\
(+12.39)\end{array}$ & $\begin{array}{c}51.25 \\
(+51.25)\end{array}$ & 0.0 \\
\hline 8 & Abnormal moth (\%) & $\begin{array}{c}39.60 \\
(+39.60)\end{array}$ & $\begin{array}{c}70.83 \\
(+70.83)\end{array}$ & 0.0 & 0.0 & 0.0 \\
\hline 9 & Total number of eggs/female & $\begin{array}{c}132.5 \pm 37.5 \\
(-84.79)\end{array}$ & $\begin{array}{l}66.0 \pm 34 \\
(-92.42)\end{array}$ & $\begin{array}{c}170.1 \pm 25.5 \\
(-80.47)\end{array}$ & $\begin{array}{c}122.50 \pm 22 \\
(-85.93)\end{array}$ & $871.2 \pm 20$ \\
\hline 10 & Hatchability (\%) & $\begin{array}{c}87.16 \\
(-12.84)\end{array}$ & $\begin{array}{c}81.81 \\
(-18.19)\end{array}$ & 100 & 100 & 100 \\
\hline 11 & Sterility (\%) & 86.74 & 93.80 & 0.0 & 0.0 & 0.0 \\
\hline
\end{tabular}

Numbers between brackets represent percent increase or decrease than control.

Means \pm SD 
Table 2 . Effect of diflubenzuron on biotic potential of $4^{\text {th }}$ instar larvae of $S$. littoralis.

\begin{tabular}{|c|c|c|c|c|}
\hline \multicolumn{2}{|c|}{ Organic compound } & \multicolumn{2}{|c|}{ Diflubenzuron (I.G.R.) } & \multirow[b]{2}{*}{ Control } \\
\hline \multicolumn{2}{|r|}{ Developmental stages } & \multirow{2}{*}{$\begin{array}{c}\mathrm{LC}_{25} \\
(4.8 \mathrm{ppm}) \\
33.92\end{array}$} & \multirow{2}{*}{$\begin{array}{c}\mathrm{LC}_{50} \\
(11.39 \mathrm{ppm}) \\
60.71\end{array}$} & \\
\hline 1 & Mortality (\%) during larval stage & & & 6.67 \\
\hline 2 & Larval stage (days) & $36.66 \pm 1.15$ & $42.66 \pm 3.05$ & $26.66 \pm 0.57$ \\
\hline & & $(+37.50)$ & $(+60.01)$ & \\
\hline \multirow[t]{2}{*}{3} & Pupal stage (days) & $36.14 \pm 1.15$ & $39.39 \pm 1.52$ & $25.33 \pm 1.15$ \\
\hline & & $(+42.67)$ & $(+55.50)$ & \\
\hline \multirow[t]{2}{*}{4} & Pre-oviposition period (days) & $6.66 \pm 0.57$ & $11.00 \pm 1$ & $3.66 \pm 0.57$ \\
\hline & & $(+81.96)$ & $(+200.54)$ & \\
\hline \multirow[t]{2}{*}{5} & Average weight of pupae (gm) & $0.202 \pm 0.008$ & $0.171 \pm 0.01$ & $0.237 \pm 0.01$ \\
\hline & & $(-14.76)$ & $(-27.84)$ & \\
\hline \multirow[t]{2}{*}{6} & Pupation (\%) & 61.66 & 36.66 & 93.33 \\
\hline & & $(-33.94)$ & $(-60.72)$ & \\
\hline \multirow[t]{2}{*}{7} & Abnormal pupae (\%) & 32.14 & 55.23 & 0.0 \\
\hline & & $(+32.14)$ & $(+55.23)$ & \\
\hline \multirow[t]{2}{*}{8} & Abnormal moth (\%) & 19.04 & 41.67 & 0.0 \\
\hline & & $(+19.04)$ & $(+41.67)$ & \\
\hline \multirow[t]{2}{*}{9} & Total number of eggs/female & $152.4 \pm 23$ & $102.0 \pm 15$ & $743 \pm 57$ \\
\hline & & $(-79.48)$ & $(-86.27)$ & \\
\hline \multirow[t]{2}{*}{10} & Hatchability (\%) & 83.59 & 68.62 & 97.30 \\
\hline & & $(-14.09)$ & $(-29.47)$ & \\
\hline 11 & Sterility (\%) & 82.37 & 90.32 & 0.0 \\
\hline
\end{tabular}

Numbers between brackets represent percent increase or decrease than control.

Means \pm SD

\section{Effect on larval duration}

Tables (1 and 2) indicated that effect of feeding $4^{\text {th }}$ instar larvae (in case of diflubenzuron) and $2^{\text {nd }}$ instar larvae (in case of $B$. thuringiensis and lettuce oil extract) on treated castor bean leaves at $\mathrm{LC}_{50}$ and $\mathrm{LC}_{25}$ on larval duration. It is obvious that 
tested compounds (diflubenzuron and B.t Agerin ) significantly prolonged the larval duration than control.

Regarding diflubenzuron, it increase the larval period by $60.01 \%$ and $37.5 \%$ at $\mathrm{LC}_{50}$ (11.39 ppm) and $\mathrm{LC}_{25}(4.8 \mathrm{ppm})$, respectively. In case of $B$. thuringiensis (agerin), the larval duration was extended by $24.74 \%$ and $13.31 \%$ for the $2^{\text {nd }}$ instar larvae at two tested levels, $\mathrm{LC}_{50}\left(19.3 \times 10^{3} \mathrm{ppm}\right)$ and $\mathrm{LC}_{25}\left(9.5 \times 10^{3} \mathrm{ppm}\right)$ respectively.

The above mentioned results proved that diflubenzuron (I.G.R.'s) seem to be more effective in increasing larval duration than $B$. thuringiensis.

While, $2^{\text {nd }}$ instar larvae (in case of lettuce oil extract) at $\mathrm{LC}_{50}\left(3.64 \times 10^{4} \mathrm{ppm}\right)$ and $\mathrm{LC}_{25}\left(2.4 \times 10^{4} \mathrm{ppm}\right)$ levels reduced the larval duration by $27.34 \%$ and $12.57 \%$ comparing with that of control, respectively.

\section{Effect on pupal duration}

Tables (1 and 2 ) showed the effect of feeding $4^{\text {th }}$ instar larvae (in case of diflubenzuron) and $2^{\text {nd }}$ instar larvae (in case of $B$. thuringiensis and lettuce oil extract) on treated castor bean leaves at $\mathrm{LC}_{50}$ and $\mathrm{LC}_{25}$ levels on duration of the resulting pupae. It is obvious that (diflubenzuron and $B$. thuringiensis) significantly prolonged the duration of pupal period than that of the untreated check. The effect of diflubenzuron, showing an increase in the pupal period by $55.5 \%$ and $42.67 \%$ at the tested levels than that of the control, respectively. In the case of $B$. thuringiensis (agerin), the pupal duration was extended by $38.50 \%$ and $10.8 \%$ for the $2^{\text {nd }}$ instar larvae at two tested levels, respectively. The above mentioned results proved that diflubenzuron seems to be more effective in increasing pupal duration percentage than B. thuringiensis, while lettuce oil extract was least effective against $2^{\text {nd }}$ instar larvae at two tested concentrations showing a decrease in the pupal duration by $33.93 \%$ and $14.91 \%$ at the two tested levels, respectively.

\section{Effect on pre-oviposition period}

Tables (1 and 2) represent the effect of the tested compounds on the preoviposition period of $S$. littoralis adult females. It is apparent that $4^{\text {th }}$ instar larvae reared on castor been leaves treated with diflubenzuron, significantly increased the pre-oviposition period . The percentages of increasing were $200.54 \%$ and $81.96 \%$ at the two tested levels $\mathrm{LC}_{50}$ and $\mathrm{LC}_{25}$, respectively. The same trend was observed when $2^{\text {nd }}$ instar larvae were reared on castor been leaves with $B$. thuringiensis (agerin) at the concentrations of $\mathrm{LC}_{50}$ and $\mathrm{LC}_{25}$. The rate of treated increase in pre-oviposition period were $(237.91 \%$ and $115.16 \%)$, respectively than that of control. On the contrary, lettuce oil, significantly decreased the pre-oviposition period with $57.97 \%$ and $31.59 \%$ than that of control. 
Our results are in agreement with the results obtained by Zidan et al. (1996) who found that $B$. thuringiensis had prolonged larval duration and adult longevity.

\section{Effect on pupal stage}

As shown in Tables (1 and 2) is apparent that feeding newly moulted $4^{\text {th }}$ instar and $2^{\text {nd }}$ instar larvae for 48 hours on castor bean oil leaves treated with diflubenzuron, B. thuringiensis and lettuce oil extract at $\mathrm{LC}_{50}$ and $\mathrm{LC}_{25}$ levels induced $(60.72 \%$, $33.94 \%)$ and $(72.42 \%, 51.73 \%)$ and $(67.24 \%, 62.03 \%)$ percent reduction in the pupation, respectively.

\section{Effect on pupal weight}

Results in Tables (1 and 2) showed that diflubenzuron and B. thuringiensis caused a moderate reduction in pupae weight by $(27.84 \%, 14.76 \%)$ and $(21.23 \%$, $14.60 \%$ ) in comparison with control, while lettuce oil extract caused an increase in pupal weight with $(35.39 \%, 30.97 \%)$ for the two concentration tested comparing with that of control .

\section{Abnormalities in pupal stage}

Data presented in Tables ( 1 and 2 ) showed that all tested compounds had a great effect on the abnormalities in the resulting pupae with different degrees. The rate of pupal abnormalities were $(55.23 \%, 32.14 \%)(72.08 \%, 26.57 \%)$ and $(51.25 \%$, $12.39 \%$ ) for diflubenzuron, $B$. thuringiensis and lettuce oil extract, respectively in comparison with control.

\subsubsection{Abnormalities in adult stage}

Data in Tables (1 and 2) showed that B. thuringiensis was the most effective compound for abnormalities of adult stage followed by diflubenzuron showing $(70.83 \%, 39.60 \%),(41.67 \%, 19.04 \%)$ for $B$. thuringiensis, and diflubenzuron, respectively. While lettuce oil extract had no effect in this respect .

Our results are in agreement with those of El-Ghar et al. (1995) who found that thuringiensin, abamectin and diflubenzuron especially abamectin, resulted in a pronounced decrease of pupation in both susceptible (16-26\%) and field (9.4-36.0\%) strains compared with the control (78.7 and $70.8 \%$, resp). The mean weight of pupae was deceased. Also, El-Lakwah et al. (1998) found that mortality and malformation rates of larval instars, pupae and adults were clearly increased with neemazal treatment.

\section{Effect on egg production}

The effect of larval treatment with diflubenzuron, B. thuringiensis (agerin) and lettuce oil extract on the egg production of the resulted adult are given in Tables (1 and 2). Examination of the tabulated data indicated that diflubenuzron reduced 
number of eggs at $\mathrm{LC}_{50}$ and $\mathrm{LC}_{25}$ concentration with $86.27 \%$ and $79.48 \%$ reduction than control, respectively.

The same trends were observed in Bacillus thuringiensis and lettuce oil extract treatments which reduced significantly the number of eggs of adult females treated as $2^{\text {nd }}$ instar larvae at $\mathrm{LC}_{50}$ and $\mathrm{LC}_{25}$ levels. The percent reduction were $(92.42 \%$, $84.79 \%)$ and $(85.93 \%, 80.47 \%)$ than control in case of $B$. thuringiensis and lettuce oil extract, respectively.

Results proved that $B$. thuringiensis (agerin) seem to be more effective in decreasing the numbers of eggs percentage than diflubenzuron and lettuce oil extract.

\section{Effect on hatchability}

It is obvious that the two tested compounds diflubenzuron and $B$. thuringiensis (agerin) reduced significantly, the fertility of deposited eggs. Also, it is noticed that diflubenzuron at the tested levels $\mathrm{LC}_{50}$ and $\mathrm{LC}_{25}$ reduced the percent hatchability with $29.47 \%$ and $14.09 \%$ than control, respectively (Table 2 ). Regarding the effect of $B$. thuringiensis (agerin) on the egg hatchability (Table 1 ), it is clear that this compound at the two tested levels obtained from the treated $2^{\text {nd }}$ instar larvae, reduced egg hatchability by $18.19 \%$ and $12.84 \%$, while lettuce oil didn't have any effect in this respect .

The above results are strongly supported by those of El-Ghar et al. (1995), who found that fecundity of the field strain was greatly reduced, especially in thuringiensin $(65.2-89 \%)$ and abamectin (57.6\%-87.4\%) treatment compared with that of control. Also, El-Lakwah et al. (1998) found that the mean number of eggs laid and hatching were reduced for neemazal treatment.

\section{Effect on sterility:}

The two tested compounds (diflubenzuron and B. thuringiensis) exhibited a high sterilizing effect showing $90.32 \%$ and $82.37 \%$ percent of sterility at $\mathrm{LC}_{50}$ and $\mathrm{LC}_{25}$ for diflubenzuron, respectively (Table 2) while B. thuringiensis (agerin) (Table 1), exhibited $(93.8 \%, 86.74 \%)$ of sterility. Results concluded that $B$. thuringiensis was more effective than diflubenzuron on sterility of adult stage resulted from treated larvae of $S$. littoralis. 


\section{REFERENCES}

1. Chamberlain, W.F. 1962. Chemical sterilization of screw worm. J. Econ. Entomol., 55: 240-248 .

2. EL-Deeb , W.M.H.,Y.F.E., Ghouneim and EL-Helmy. 1991. Potential use of the juvenile hormone mimic pyriproxyfen for the control of Spodoptera littoralis (Boisd) . 4th Arab Congress Plant Prot . Cairo, 1-5 Dec.

3. EL-Dewy, M.F.H. 2006. Toxicological studies on some pests attacking cotton. Ph. D. Thesis, Fac. Agric. , Kafrelsheikh Univ.

4. El-Ghar, G.E.S., H.S.A. Radwan, Z.A. El-Bermawy and L.T.M. Zidan. 1995. Sublethal effects of avermectin B1, beta-exotoxin of Bacillus thuringiensis and diflubenzuron against cotton leafworm (Lep., Noctuidae). J. Appl. Entomol., 119(4): 309-313.

5. El-Lakwah, F.A., A.A. Darwish, H.A. Abdel-Wahab and H.S. Shaalan. 1998. Susceptibility of cotton leafworm Spodoptera littoralis (Boisd.) to neemazol and some biological observations resulted from larval treatment. Annals Agric. Sci., Moshtohor, 36(2): 1157-1170.

6. EL-Shoura ,M.Y. and M.I. Aly. 1994. Efficacy of three IGR'S alone and in mixtures with methomyl on cotton leafworm larvae Spodoptera littoralis . J.Agric. Sci . Mansoura Univ. 19 (1) : 357 -363.

7. Gomaa , E.A.A., G. M. Moawad, W.M.H. Desuky, A.A.EL-Sheakh and S.A.A. Raslan. 1996. Feedings response, Biological and toxicological potential of some IGR's ON Spodoptera littoralis . Egypt J.Agric. Res., 74(1),91-100.

8. Ishaaya, L., A.Novon and E. Gurevitz. 1986. Comparative toxicity of chlorfluazuron (IKL-7899) and cypermethrin to Spodoptera littoralis, Lobesia botrana Drosophila melanogaster . Crop Protection , 6:385-388.

9. Korkor, A.A., M.Z.F., Awad, A.M.Hamid , A.R.Farrag and F.A. EL-Santil. 1996. Role of insect development inhibitors and insect growth regulators in controlling cotton leafworm Spodoptera littoralis in cotton fields .J.Agric. Sci. Mansoura Univ. 21 (1):361-371.

10. Toppozada, A., S.A. Abdallah and M.E. El-Defrawi. 1966. Chemosterilization of larvae and adults of the Egyptian cotton leafworm , P. litura F . by apholate , metepa and tepa . J . Econ. Entomol. , 59 : 1125-1128.

11. Zidan, Z.H., G.M. Moawad, S.A. Emara and F.E. El-Sweeki. 1996. Biological activities of certain non-toxic compounds against the cotton leafworm, Spodoptera littoralis (Boisd). Annals. Agric. Sci. Cairo, Special Issue, 265-278. 


\section{تأثير بعض المبيدات الحشرية على الاثتدار الحيوي لاودة ورق القطن}

صفوت عبد السلام عارف1 ، عثمان شكرى عبده بيومى2 ، هبه على بسيونى سليمان 1

$$
\text { r ا ـ ـ كعهة بحوث وقاية النباتات - مركز البحوث الزراعبة - الدقى - جبزة }
$$

أدت معاملة يرقات العمر الر ابع بالجر عة النصف مميتة LC50 و ونصفها 4825 لمدة 48 ساعة

$$
\text { على ورق خروع معامل بمركب دايفلوبنزيورون الى : }
$$

نسبة موت 60.71 \% ، 33.92 \% . - طول فترة العمر اليريقي بمقدار 60.01 \% ، 37.5 \% . - اطالة فترة التعذير بمقدار 55.5 \% ، 42.67 \% ـ - اطالة مدة ما قبل وضع البيض بمقدار 200.54 . \% 81.96 ، \% - خفض وزن العذاري الناتجة بمقدار 27.84 \% ، 14.76 \% ـ ـ - زيادة نسبة العذاري المشوهه بمقدار . \% 32.14 ، \% 55.23

- زيادة نسبة الفر اشـات المشوهه بمقدار 41.67 \% ، 19.41 \% ـ ـ خفض عدد البيض لكل انثى بمقدار 86.27 \% ، 79.48 \% . - نسبة عقم فى البيض بمقدار 82.37 \% 90.32 وذلك مقارنة بالكنترول

أدت معاملة يرقات العمر الثانى بالجر عة النصف ممينة LC50 و ونصفها

$$
\text { على ورق خروع بركب الباسيلس ثيورنجنسز الي : }
$$

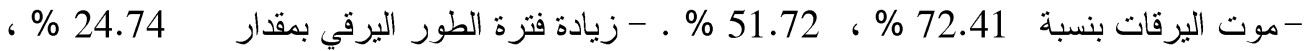
$\% 13.31$

- اطالة فترة التعذير بمقدار 38.5 \% ، 10.80\% ـ - اطالة مده ما قبل وضع البيض بمقدار 237.91 \% \%115.16 。

- خفض وزن العذاري الناتجة بمقدار 21.23 \% ، 14.60 \% ـ - زيادة العذاري المشوهه بنسبة 72.08 . \% 26.57 ، \%

- زيادة نسبة الفر اثات المشو هل بمقدار 70.83 \% ، 39.60 \% ـ ـ خفض نسبة البيض لكل انثي بمقدار 92.42 \% ، 84.79 \% . - نسبة العقم فى البيض بمقدار 93.80 \% ، 86.74 \% وذلك مقارنة

أدت معاملة يرقات العمر الثانى بالجر عة النصف مميتة LC50 و ونصفها

$$
\text { على ورق خروع بمركب زيت الخس الي : }
$$

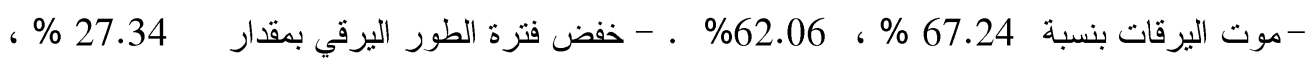
. $\% 12.57$

$$
\begin{aligned}
& \text { - خفض فترة التعذير بمقدار } 33.93 \text { \% ، 14.91\%. - خفض مده ما قبل وضع البيض بمقدار } \\
& \text {. \%31.59، \%57.97 }
\end{aligned}
$$

- زيادة وزن العذاري الناتجة بمقدار 35.39 \% 30.97 \% ـ - زيادة العذاري المشوهه بنسبة . \% 12.39 \% \% 51.25

- خفض عدد البيض لكل انثي بمقدار 85.93 \% ، 80.47 \% ـ - لم يؤثر زيت الخس على الفراثات و على نسبة فقس البيض و العقم وذلك مقارنة بالكنترول . 